\title{
Factors of Video Directly Observed Therapy Adoption in Malaysia
}

Fariha Anjum Hira, Haliyana Khalid, Anuradha Shashikala, Alam Md Moshiul

To Link this Article: http://dx.doi.org/10.6007/IJARBSS/v12-i1/11977

DOI:10.6007/IJARBSS/v12-i1/11977

Received: 05 November 2021, Revised: 09 December 2021, Accepted: 27 December 2021

Published Online: 07 January 2022

In-Text Citation: (Hira et al., 2022)

To Cite this Article: Hira, F. A., Khalid, H., Shashikala, A., \& Moshiul, A. M. (2022). Factors of Video Directly Observed Therapy Adoption in Malaysia. International Journal of Academic Research in Business and Social Sciences, 12(1), 971-982.

\section{Copyright: (C) 2022 The Author(s)}

Published by Human Resource Management Academic Research Society (www.hrmars.com)

This article is published under the Creative Commons Attribution (CC BY 4.0) license. Anyone may reproduce, distribute, translate and create derivative works of this article (for both commercial and non0-commercial purposes), subject to full attribution to the original publication and authors. The full terms of this license may be seen at: http://creativecommons.org/licences/by/4.0/legalcode

\section{Vol. 12, No. 1, 2022, Pg. $971-982$}

Full Terms \& Conditions of access and use can be found at http://hrmars.com/index.php/pages/detail/publication-ethics 


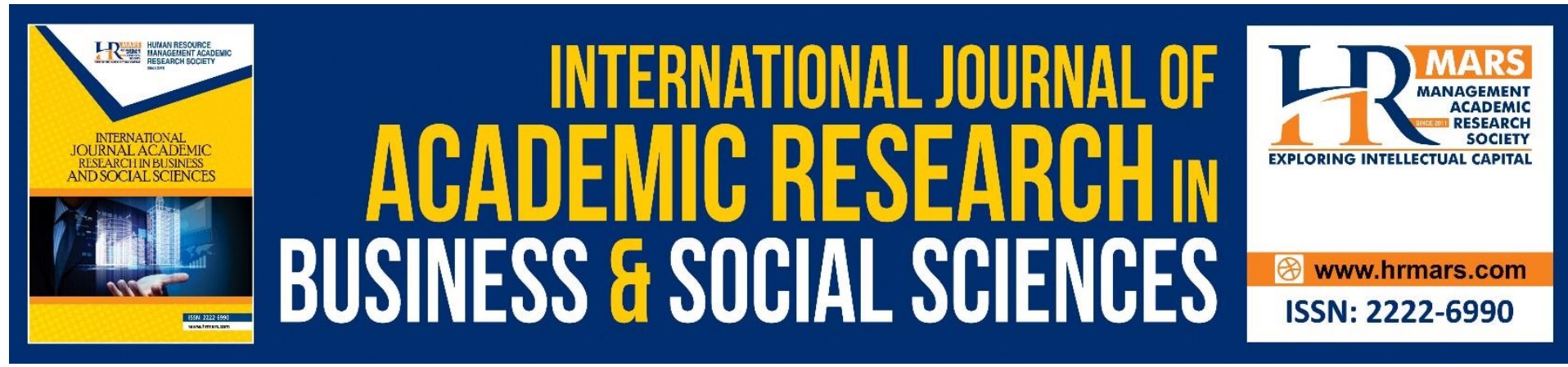

\title{
Factors of Video Directly Observed Therapy Adoption in Malaysia
}

\author{
Fariha Anjum Hira ${ }^{1}$, Haliyana Khalid ${ }^{1}$, Anuradha Shashikala ${ }^{1}$, \\ Alam Md Moshiul ${ }^{2}$ \\ ${ }^{1}$ Azman Hashim International Business School, Universiti Teknologi Malaysia, Kuala Lumpur \\ 54100, Malaysia, ${ }^{2}$ Razak Faculty of Technology and Informatics, Universiti Teknologi \\ Malaysia, Kuala Lumpur 54100, Malaysia \\ Corresponding Author: hirafa92@gmail.com
}

\begin{abstract}
Remote patient monitoring using mobile devices can be a cost-effective, time-saving solution limiting patient mobility. Direct observation of therapy (DOT) of tuberculosis patients in Malaysia usually involves traveling to the healthcare facility. Due to the contagious nature of the disease, who comes into contact with patients is at risk of developing it. Additionally, DOT is time-consuming and costly for patients. A smartphone application for remote tuberculosis patient monitoring called video directly observed therapy (VDOT) can be a cost-effective and safer way of patient monitoring. However, before implementing this technology, the user readiness assessment helps policymakers' decision-making. This pre-implementation phase study aims to ascertain users' intent to utilize the VDOT app. The current study examines users' readiness using a modified Unified Theory of Acceptance and Use of Technology (UTAUT). The cross-sectional survey took place in Selangor and the federal territory of Kuala Lumpur, Malaysia. A total of 220 questionnaires were delivered to prospective users, including patients and family members. $68 \%$ percent of the questioners were deemed usable and were evaluated using SPSS. The study's findings indicate that users intend to adopt the VDOT app for tuberculosis remote monitoring. Performance expectancy, social influence, facilitating conditions, and trust influence users' behavioral intention to adopt the VDOT app in Malaysia.
\end{abstract}

Keywords: Malaysia, Mhealth, Public Health, Technology Acceptance, Trust, Tuberculosis, VDOT

\section{Introduction}

Despite increased global awareness and diagnostic efforts, tuberculosis continues to be a significant cause of fatality, even though a few kinds of tuberculosis are curable (Baya et al., 2019; Subbaraman et al., 2018). Tuberculosis is still a major public health issue because, after the Human Immunodeficiency Virus (HIV), it is the second-highest cause of mortality among adults (Atif et al., 2014). Globally, approximately 11 million new cases of tuberculosis occur each year, and over two million people die from active tuberculosis (Baya et al., 2018; Subbaraman et al., 2018; Tok et al., 2020). By 2020, it was anticipated that the global 
tuberculosis epidemic would exceed a billion people. The goal was to achieve a $35 \%$ decrease in active patient numbers (Atif et al., 2014). Before the COVID-19 pandemic, nearly 4000 people perished each day from tuberculosis (McQuaid et al., 2020; WHO, 2019). The impact of this public health emergency on tuberculosis is unknown and consequently remains a matter of apprehension (Wingfield et al., 2020). Besides, this issue has not been thoroughly addressed in any recent study (Glaziou, 2020). It is currently uncertain if the social distance can compensate for tuberculosis care delivery disruptions or the likely impact of these combined COVID-19 disruptions on the tuberculosis burden (McQuaid et al., 2020). The COVID-19 public health emergency is impacting the treatment of other diseases. The pandemic poses a threat to meeting the tuberculosis diminishing target on time. By 2035, the World Health Organization (WHO) hopes to reduce tuberculosis-related mortality by $95 \%$ and tuberculosis incidence by $90 \%$. Thus, effective patient management programs should be devised to accomplish this objective, which is necessary to benefit both patients and the community (Uplekar et al., 2015). A novel or improved way of treating tuberculosis must be considered and analyzed to achieve the worldwide target strategy of tuberculosis elimination (The World Bank, 2017).

Tuberculosis is still regarded as one of Malaysia's five most infectious illnesses. As a result, tuberculosis outbreaks continue to pose a severe challenge to the countries' healthcare systems. The success rate of pulmonary tuberculosis treatment is 85 percent (Atif et al., 2014). Due to the contagious nature of the disease, notably pulmonary tuberculosis, treatment, and prevention are challenging for the healthcare system as they are dangerous for public health (Subbaraman et al., 2018). A variety of tuberculosis infections require roughly 180 days of daily therapy (Do et al., 2019; Johnston, Campbell \& Menzies, 2017). Tuberculosis patients in Malaysia visit healthcare facilities daily, or a skilled healthcare service provider visits patients' homes to verify medication compliance. This treatment technique is referred to as Direct Observation of Therapy (DOT) (The World Bank, 2017; Story et al., 2016). Although the DOT's direct supervision strategy enhances compliance, it does have significant drawbacks (Lutge et al., 2015). DOT practice is inconvenient for patients and exposes them to risks from others, as the pulmonary tuberculosis virus can spread via the air. It entails aligning the patient's schedule and location with the DOT service provider's routine medication. These barriers prompted the development of mHealth interference dubbed Video Directly Observed Therapy (VDOT) as a means of circumventing such barriers in lieu of DOT adherence (Garfein et al., 2015). The WHO (2015) recommended using communication technology in healthcare settings, and VDOT can treat tuberculosis patients via mobile phone applications. mHealth (mobile health) is successfully aiding in the cessation of smoking (Finkelstein \& Cha, 2016; McClure, Hartzler, \& Catz, 2016), postoperative care, and diabetic patients' self-management, among other things (Scott et al., 2017; Wu et al., 2017). The VDOT mHealth approach can reduce tuberculosis exposure in the general community without interfering with patients' daily lives. In some high-income countries, the feasibility analysis has revealed favorable research outcomes for VDOT mHealth (Eshet, Reuver \& Bouwman, 2017; WHO, 2015).

VDOT is a drug administration monitoring technique that records and transmits digital images of patients' medication ingestion to a specific site for the caregiver's reference. A patient records footage using a smartphone application with a date and time stamp during medicine consumption and then shares it with a healthcare service provider. The clinical supervisor can then monitor and record each dose administered to the patient (WHO, 2015). VDOT enables two distinct strategies. One is real-time, while the other is patient-recorded video sharing. As a result, a simple monitoring strategy for tuberculosis patients provides 
flexibility for both parties (Eshet et al., 2017; WHO, 2015). VDOT serves as a daily reminder to take medications. Throughout therapy, patients can contact their clinical supervisor using mobile phone messaging, emailing, and calling capabilities (WHO, 2015). Understanding user's perception is important before implementing any technology in the healthcare industry (Hira et al., 2021). Research has also been conducted on designing features in the VDOT to support distress and loneliness, emotional states that tuberculosis patients always experience during their treatment (Khalid \& Ghazali, 2019). However, a modest number of studies have been done to ascertain users' intentions about using VDOT services. This study aims to create an awareness of patients' convenience when using mobile health applications to aid in the design and development of the VDOT app. This research seeks to ascertain the parameters influencing VDOT adoption among the general population in peninsular Malaysia.

\section{Literature Review and Hypothesis}

Mobile applications are computer programs optimized for use on portable electronic devices, including smartphones and tablets (Edwards et al., 2016). Medical-related app usage has increased to 500 million (Khechine, Lakhal \& Ndjambou, 2016). From the perspective of healthcare app developers, it is critical to understand the factors that drive app uptake and sustained use to create effective apps. The introduction of VDOT could have a substantial impact on public health. It is critical to study how users perceive and forecast their future use of this health app. VDOT acceptance in Malaysia has received scant attention, although some researchers have evaluated the behavioral intention of VDOT adoption in another foreign context using the UTAUT (WHO, 2015; Eshet, de Reuver \& Bouwman, 2017). This study intends to empirically validate the conceptual model in the Malaysian context. One of the most widely used technologies adoption theories, UTAUT has four IVs and four moderators, as depicted in Figure 1.

Figure.1 UTAUT model (Venkatesh et al. (2003).

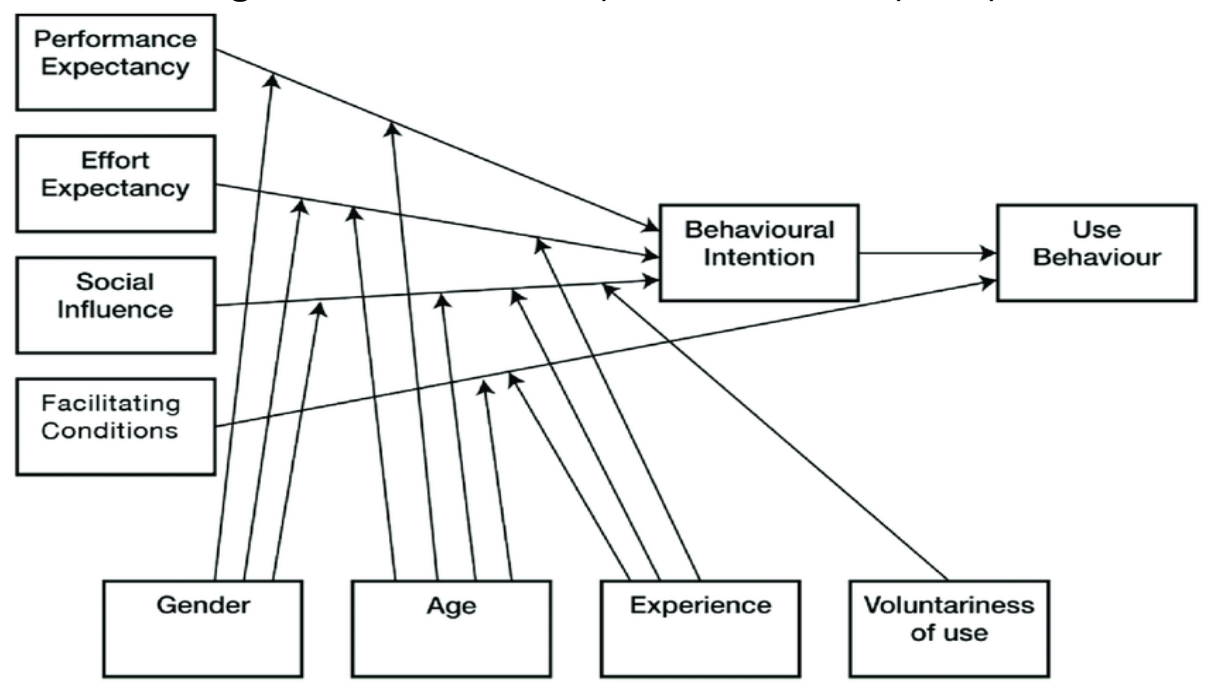

Numerous past studies have employed a modified version of this model; for example, Foon and Fah (2011) incorporated trust as an additional feature and eliminated four moderators, and use behavior from UTAUT. The study found a significant correlation between IVs and DV. Hence, we have added technology trust as an Individual variable (IV) to modify UTAUT, as Fox and Connolly (2018) suggested. This model focuses more on individuals' behavior that suits this study's objectives to examine the associated preadoption factors, as shown in Figure 2. Figure.2 Conceptual model. 


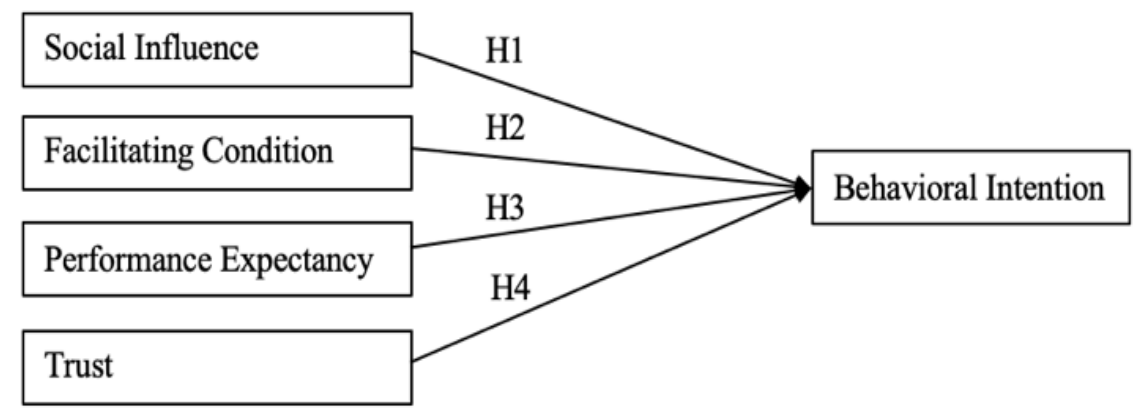

\section{Performance Expectancy}

The performance expectancy (PE) of technology is the level to which it can increase the productivity or effectiveness of its clients (Venkatesh \& Zhang, 2010). PE was established by integrating the Technology Acceptance Model's (Davis, 1989) perceived usefulness, the Social Cognitive Theory's (Bandura, 1986) outcome expectation, and the Incentive Model's external motivation (Davis, Bagozzi \& Warshaw, 1992). PE directly influences the behavioral intention of users towards mHealth (Skoumpopoulou et al., 2018; Seethamraju, Diatha \& Garg, 2018). Users' understanding of the possible benefits of VDOT will increase the chances of intent to adopt it. VDOT is expected to eliminate the risk of infection, improve cost-efficiency by cutting travel expenses, improve efficient intervention, and smoothen the users' treatment process. PE is the most significant predictor of $\mathrm{BI}$ in the UTAUT model. As a result, it is critical to investigate its relationship to the behavioral intention of understanding VDOT users' perception at the early stage of app development. Technologically knowledgeable individuals anticipate fewer complications when utilizing mobile apps to check tuberculosis status and rapidly become acclimated to it (Yuan, Kanthawala \& Peng, 2015). The following hypothesis is proposed: If users have a high expectation of performance, they are more likely to create a usage intention to utilize VDOT.

H1: Performance expectancy positively influences behavioral intention to use VDOT.

\section{Social Influence}

The term "social influence" ( $\mathrm{SI}$ ) refers to the degree to which users value the beliefs of others (Davis, 1989). It was derived from subjective norms in Ajzen's (1991) Theory of Planned Behavior and the Theory of Reasoned Action by Fishbein and Ajzen (1977). Users' decisions to adopt new apps are influenced by society's acceptability, most notably by user ratings and comments (Yadav, Sharma \& Tarhini, 2016). In other words, the opinions of family, friends, peers, and other users influence and affect end-users choices. If an app is desirable and beneficial, users will follow their referees' advice, greatly increasing behavioral Intention to use mHealth through SI (Wang, \& Chou, 2016). SI found to have a significant positive influence on users' intentions to adopt mHealth (Arenas Gaitán, Peral Peral, \& Ramón Jerónimo, 2015). VDOT offers new services to tuberculosis patients via a relatively new service delivery channel. Therefore, it is expected that users will be interested in others' opinions based on their experiences and views of using VDOT. From peers, friends, and family, patients are likely to develop different perceptions about VDOT. As a result, the VDOT adoption intention is deemed high if $\mathrm{SI}$ is favorable.

$\mathrm{H} 2$ : Social influence positively influences behavioral intention to use VDOT. 


\section{Facilitating Condition}

Facilitating Conditions (FC) are the motivating factors that demonstrate the comfort or simplicity technology may be used to purchase things and services. It depicts extrinsic restrictions on behavior that limit the availability of resources and technology enabling circumstances (Eshet, de Reuver \& Bouwman, 2017; Yuan et al., 2015). The research reveals and demonstrates the importance of support personnel's availability of guidance in assisting users in overcoming technological restrictions. On the other side, enabling conditions emphasize the need for a technologically enabled environment to minimize barriers to technology use, hence facilitating customers' use of mHealth app features. Conducive conditions, for example, improved interface, speed, data processing capabilities, and individual awareness of mobile functions and features, will compel the user to adopt VDOT.

H3: Facilitating condition positively influences behavioral intention to use VDOT.

\section{Trust}

Trust is considered a substantial factor in reducing insecurity feelings that assure user intention towards new technology. Technology Trust positively impacts the intention to use technology (Suki \& Suki, 2017). Security concerns over mobile apps relating to privacy may stimulate users' trust (Wang \& Chou, 2016). Technology trust can be enhanced via an interface with ease of use and the belief in the web interface's safety mechanism. Prospective clients will be motivated to utilize mobile applications if they believe and trust that the app will provide a short wait time, increased convenience, and efficiency. Vulnerability is associated with an initial propensity to take risks despite the possibility of losing critical knowledge.

H4: Trust positively influences behavioral intention to use VDOT.

\section{Behavioural Intention}

"Behavioral Intention" refers to an individual's proclivity to perform or abstain from performing a specified future behavior (Venkatesh \& Zhang, 2010). Suki and Suki (2017) found that individuals are more likely to engage in a given behavior if their intention toward the behavior is positive. This is a patient-centric study addressing the factors of mobile app-based VDOT adoption. Respondents are asked whether they will adopt the VDOT mobile app once it is available for use.

\section{Method}

\section{Population and Sample}

Malaysian users 18 years and older with at least one year of experience using mHealth apps were considered respondents. According to the geographical location, this study evaluated two states of Malaysia, namely, Selangor and Federal Territory, for sample collection. Firstly, considering the number population. Secondly, more than 30 percent of mobile phone users reside in these areas (Quoquab et al., 2018). The study implied a convenience method using a floating questionnaire to readily reachable users. Individuals in several public places such as hospitals, university campuses, and university medical centers voluntarily participated as respondents in this study. The respondent from these areas was suitable because of the type of organization. It is believed that the individuals from these premises are supposed to be interested in using mHealth apps than others. Due to ongoing public health emergencies and time constrain, the random sampling method could not be implied. A total of 220 
questionnaires were distributed, but 173 questionnaires were received from the identified respondents. One hundred fifty questionnaires (68\%) could be retained for further analysis using the statistical package for the social sciences (SPSS) software.

\section{Data Collection and Analysis}

The current study used a quantitative method to assess the conceptual model experimentally to ascertain users' intentions to use VDOT apps for tuberculosis treatment. To quantify the study variables from the preceding literature, a Likert scale of 5 ( $1=$ "strongly disagree," $5 \mathrm{i}=$ "strongly agree"). Items for $\mathrm{PE}, \mathrm{SI}, \mathrm{FC}, \mathrm{BI}$ have been adopted and adapted from Abrahão, Moriguchi, and Andrade (2016). Items for trust have been adapted from Harris, Brookshire, and Chin (2016) and presented in Table 1.

Table.1. The variables and utilized items

\begin{tabular}{|c|c|c|}
\hline Variable & Code & Items \\
\hline \multirow[t]{3}{*}{$\begin{array}{l}\text { Performance } \\
\text { Expectancy }\end{array}$} & PE1 & $\begin{array}{l}\text { If I had tuberculosis, using Mobile Apps for my treatment could } \\
\text { be useful in my daily life (Ex: Reducing traveling costs \& time) }\end{array}$ \\
\hline & PE2 & $\begin{array}{l}\text { If I had tuberculosis, using Mobile Apps for treatment could help } \\
\text { me to accomplish everyday tasks quickly }\end{array}$ \\
\hline & PE3 & $\begin{array}{l}\text { If I had tuberculosis, using Mobile Apps for treatment, I could } \\
\text { help improve tuberculosis monitoring }\end{array}$ \\
\hline \multirow[t]{3}{*}{$\begin{array}{l}\text { Social } \\
\text { Influence }\end{array}$} & SI1 & $\begin{array}{l}\text { My doctor would think I should use Mobile Apps for therapy if I } \\
\text { had tuberculosis }\end{array}$ \\
\hline & $\mathrm{SI} 2$ & $\begin{array}{l}\text { My family would think I should use Mobile Apps for treatment if } \\
\text { I had tuberculosis }\end{array}$ \\
\hline & $\mathrm{SI3}$ & $\begin{array}{l}\text { My friends would think I should use Mobile Apps for therapy if I } \\
\text { had tuberculosis }\end{array}$ \\
\hline \multirow[t]{3}{*}{$\begin{array}{l}\text { Facilitating } \\
\text { Condition }\end{array}$} & FC1 & $\begin{array}{l}\text { I have the necessary resources (training and knowledge) to use } \\
\text { Mobile Apps in the healthcare }\end{array}$ \\
\hline & FC2 & $\begin{array}{l}\text { I have the required assistance if I face any difficulties with } \\
\text { Mobile Apps in the healthcare }\end{array}$ \\
\hline & FC3 & $\begin{array}{l}\text { I find Mobile Apps in healthcare compatible with other systems } \\
\text { or appliances I use }\end{array}$ \\
\hline \multirow[t]{3}{*}{ Trust } & TR1 & The mobile Apps market in healthcare is trustworthy \\
\hline & TR2 & $\begin{array}{l}\text { The mobile Apps market in healthcare has my best interests in } \\
\text { mind }\end{array}$ \\
\hline & TR3 & The mobile Apps market in healthcare has high integrity \\
\hline \multirow[t]{3}{*}{$\begin{array}{l}\text { Behavioral } \\
\text { Intention }\end{array}$} & $\mathrm{Bl1}$ & $\begin{array}{l}\text { If I had tuberculosis, I intend to use Mobile Apps for treatment } \\
\text { when it is available }\end{array}$ \\
\hline & $\mathrm{B} 12$ & $\begin{array}{l}\text { If I had tuberculosis, I would use Mobile Apps for therapy in the } \\
\text { next six months }\end{array}$ \\
\hline & $\mathrm{BI3}$ & $\begin{array}{l}\text { If I had tuberculosis, I would plan to use Mobile Apps for } \\
\text { treatment in the next six months }\end{array}$ \\
\hline
\end{tabular}

A survey questionnaire was used for data collection circulated via both online and offline channels. Due to the impossibility of obtaining all members of the sample population, a nonprobability sampling technique was used. According to Kline's rule of thumb, we used a factor of 10 to calculate a minimum number of response requirements as 15 items are present in 
the survey questionnaire (Kline, 2011). The sample size found was 150- (10x15). The respondent's age is 18 years and above. The data analysis results are presented in this section. Table 2 presents relevant results. The Cronbach alpha is within an acceptable range between 0.656 to 8.37. Table 3 shows the Pearson correlation coefficient analysis outcome. The relationship between variables is at a significant level.

Table.2. Variable statistics, factor loading, Cronbach alpha, KMO \& Barlett's test.

\begin{tabular}{|l|l|l|l|l|l|l|}
\hline Variable & Mean & $\begin{array}{l}\text { Standard } \\
\text { deviation }\end{array}$ & $\begin{array}{l}\text { Item to } \\
\text { total }\end{array}$ & $\begin{array}{l}\text { Factor } \\
\text { loading }\end{array}$ & $\begin{array}{l}\text { Cronbach } \\
\text { alpha }\end{array}$ & $\begin{array}{l}\text { KMO } \\
\text { Barlett's } \\
\text { test }\end{array}$ \\
\hline $\begin{array}{l}\text { Performance } \\
\text { Expectancy }\end{array}$ & 12.340 & 1.562 & & & 0.656 & 0.650 \\
\hline PE1 & 4.050 & 0.6344 & 0.509 & 1.778 & & \\
\hline PE2 & 4.082 & 0.7113 & 0.553 & 0.668 & & \\
\hline PE3 & 4.208 & 0.6850 & 0.608 & 0.554 & & \\
\hline Social Influence & 11.390 & 2.2973 & & & 0.835 & 0.719 \\
\hline SI1 & 3.704 & 0.9109 & 0.579 & 1.256 & & \\
\hline SI2 & 3.843 & 0.9382 & 0.617 & 0.420 & & \\
\hline SI3 & 3.843 & 0.7998 & 0.665 & 0.324 & & \\
\hline Facilitating & 11.673 & 2.0822 & & & 0.711 & 0.665 \\
Conditions & 3.849 & 0.9291 & 0.648 & 1.902 & & \\
\hline FC1 & 3.874 & 0.8400 & 0.553 & 0.616 & & \\
\hline FC2 & 3.950 & 0.8479 & 0.652 & 0.482 & & \\
\hline FC3 & 11.365 & 2.0045 & & & 0.712 & 0.671 \\
\hline Trust & 3.818 & 0.8704 & 0.800 & 1.904 & & \\
\hline TR1 & 3.843 & 0.7918 & 0.743 & 0.601 & & \\
\hline TR2 & 3.704 & 0.8535 & 0.759 & 0.495 & & \\
\hline TR3 & 12.434 & 2.0578 & & & 0.837 & 0.665 \\
\hline $\begin{array}{l}\text { Behavioral } \\
\text { Intention }\end{array}$ & 4.119 & 0.7985 & 0.872 & 2.297 & & \\
\hline BI1 & 4.107 & 0.7762 & 0.756 & 0.518 & & \\
\hline BI2 & 4.208 & 0.7962 & 0.676 & 0.215 & & \\
\hline BI3 & & & & & & \\
\hline
\end{tabular}

Table.3. Correlation's outcome.

\begin{tabular}{|l|l|l|l|l|l|}
\hline Variable & PE & SI & FC & Tr & BI \\
\hline $\begin{array}{l}\text { Performance } \\
\text { expectancy }\end{array}$ & 1 & & & & \\
\hline Social Influence & $.502^{* *}$ & 1 & & \\
\hline Facilitating Condition & $.564^{* *}$ & $.552^{* *}$ & 1 & & \\
\hline Trust & $.460^{* *}$ & $.493^{* *}$ & $.583^{* *}$ & 1 & \\
\hline Behavioral Intention & $.639^{* *}$ & $.540^{* *}$ & $.652^{* *}$ & $.562^{* *}$ & 1 \\
\hline
\end{tabular}

\section{Result and Discussion}

The data validated the assumptions that the independent factors, performance expectancy, social influence, enabling conditions, and trust positively and substantially 
influence behavioral intention. The findings reaffirm that the modified UTAUT is capable of explaining the linkages adequately. Additionally, this research corroborates previous research that indicated public readiness for technology adoption in the healthcare sector. The $p$-value is less than 0.05 , meaning that the dependent and independent variables have a significant association between $\mathrm{PE}, \mathrm{SI}, \mathrm{FC}, \mathrm{TR}$, and behavioral intention.

Table.4. $\beta$ value and $p$-value.

\begin{tabular}{|l|l|l|l|l|}
\hline Hypotheses & $\boldsymbol{\beta}$ value & $\mathbf{P}$-value & $\mathbf{t}$ - value & Result \\
\hline $\begin{array}{l}\text { Performance Expectancy } \rightarrow \text { Behavioral } \\
\text { Intention }\end{array}$ & 0.328 & 0.000 & 4.878 & Supported \\
\hline Social Influence $\rightarrow$ Behavioral Intention & 0.294 & 0.000 & 3.974 & Supported \\
\hline $\begin{array}{l}\text { Facilitating Condition } \rightarrow \text { Behavioral } \\
\text { Intention }\end{array}$ & 0.178 & 0.000 & 2.621 & Supported \\
\hline Trust $\rightarrow$ Behavioral Intention & 0.125 & 0.125 & 1.853 & Supported \\
\hline
\end{tabular}

a. Dependent Variable: Behavioural Intention

\section{Conclusion}

While VDOT can be utilized anywhere, any time to assist with tuberculosis patient monitoring, the technologies' lack of adoption poses a barrier to their widespread implementation. This work aimed to propose and validate a theoretical VDOT acceptance model. We inferred a modified UTAUT to account for user acceptance of VDOT. The results indicated that all four of the predicted hypotheses were supported. Users' perceptions on performance expectancy, social influence, facilitating condition, trust can positively influence behavioral intention to adopt VDOT. Trust influences behavioral intention at the preimplementation phase. Performance expectancy, social influence, facilitating condition influences behavioral intention the most. VDOT intervention may be implemented in Malaysia for TB patients.

Nowadays, the mobile phone is utilized daily throughout the world. The cost of interventions using mobile apps is lower, and they are easily available, convenient to use. Smartphone and mobile networking technologies are advancing, creating opportunities for realistic technological intervention (Wingfield et al., 2020). This study's limitation includes that respondents were chosen voluntarily and were chosen based on their desire to use mobile technology for healthcare interventions. The study's findings may be skewed, as the respondents have been regarded as tech-savvy. Therefore did not include effort expectancy as a variable. Second, data quality can be a concern. Due to time constraints, the sample size for the analysis was somewhat small. Thirdly, participants were not provided with a prototype of the VDOT mobile application, which does not yet exist in Malaysia. As a result, participants' responses are contingent on their perception of the VDOT mHealth app. Further study could consider including a large sample size and retaining effort expectancy following the original UTAUT. Generation could influence the degree of intention to adopt technology, thus, recommended to be considered a variable. Furthermore, multiple stakeholders' perspectives (i.e., patient, caregiver) can be assessed in the future. The framework of this study could be further tested or expanded with other relevant contextual variables. 


\section{References}

Ajzen, I. (1991). The theory of planned behavior. Organizational behavior and human decision processes, 50(2), 179-211.

Gaitán, A. J., Peral, P. B., \& Jerónimo, R. M. (2015). Elderly and internet banking: An application of UTAUT2. Journal of Internet Banking and Commerce, 20 (1), 1-23.

Atif, M., Sulaiman, S. A. S., Shafie, A. A., Ali, I., \& Asif, M. (2014). Treatment outcome of new smear positive pulmonary tuberculosis patients in Penang, Malaysia. BMC Infectious Diseases, 14(1), 399.

Bandura, A. (1986). Social foundations of thought and action. Englewood Cliffs, NJ, 1986.

Baya, B., Achenbach, C. J., Kone, B., Toloba, Y., Dabitao, D. K., Diarra, B., Goita, D., Diabaté, S., Maiga, M., Soumare, D., and Ouattara, K. (2019). Clinical risk factors associated with multidrug-resistant tuberculosis (MDR-TB) in Mali. International Journal of Infectious Diseases, 81, 149-155.

Davis, F. D. (1989). Perceived usefulness, perceived ease of use, and user acceptance of information technology. MIS quarterly, 319-340.

Davis, F. D., Bagozzi, R. P., \& Warshaw, P. R. (1992). Extrinsic and intrinsic motivation to use computers in the workplace 1. Journal of applied social psychology, 22(14), 1111-1132.

de Sena Abrahão, R., Moriguchi, S. N., \& Andrade, D. F. (2016). Intention of adoption of mobile payment: An analysis in the light of the Unified Theory of Acceptance and Use of Technology (UTAUT). RAI Revista de Administração e Inovação, 13(3), 221-230.

Do, D., Garfein, R. S., Cuevas-Mota, J., Collins, K., \& Liu, L. (2019). Change in Patient Comfort Using Mobile Phones Following the Use of an App to Monitor Tuberculosis Treatment Adherence: Longitudinal Study. JMIR mHealth and uHealth, 7(2), e11638.

Edwards, E. A., Lumsden, J., Rivas, C., Steed, L., Edwards, L. A., Thiyagarajan, A., \& Taylor, S. (2016). Gamification for health promotion: systematic review of behaviour change techniques in smartphone apps. BMJ open, 6(10), e012447.

Eshet, E., de Reuver, M., \& Bouwman, H. (2017). The Role of Organizational Strategy in the User-centered Design of Mobile Applications. CAIS, 40, 14.

Foon, Y. S., \& Fah, B. C. Y. (2011). Internet banking adoption in Kuala Lumpur: an application of UTAUT model. International Journal of Business and Management, 6(4), 161.

Fox, G., \& Connolly, R. (2018). Mobile health technology adoption across generations: Narrowing the digital divide. Information Systems Journal, 28(6), 995-1019.

Finkelstein, J., \& Cha, E. M. (2016). Using a mobile app to promote smoking cessation in hospitalized patients. JMIR mHealth and uHealth, 4(2), e59.

Fishbein, M., \& Ajzen, I. (1977). Belief, attitude, Intention, and behavior: An introduction to theory and research.

Garfein, R.S., Collins, K., Muñoz, F., Moser, K., Cerecer-Callu, P., Raab, F., Rios, P., Flick, A., Zúñiga, M.L., Cuevas-Mota, J. and Liang, K. (2015). Feasibility of tuberculosis treatment monitoring by video directly observed therapy: a binational pilot study. The International Journal of Tuberculosis and Lung Disease, 19(9), 1057-1064.

Harris, M. A., Brookshire, R., \& Chin, A. G. (2016). Identifying factors influencing consumers' intent to install mobile applications. International Journal of Information Management, 36(3), 441-450.

Hira, F. A., Khalid, H., Rasid, S. Z. A., \& Alam, M. M. (2021). A Conceptual Framework to Investigate Health Professionals' Blockchain Technology Adoption Readiness in Malaysia. Open International Journal of Informatics, 9(Special Issue 2), 58-66. 
Johnston, J. C., Campbell, J. R., \& Menzies, D. (2017). Effect of intermittency on treatment outcomes in pulmonary tuberculosis: an updated systematic review and metaanalysis. Clinical Infectious Diseases, 64(9), 1211-1220.

Khalid, H., Ghazali, M., (2019) Designing technology to address distress of TB patients' emotional states: findings from contextual inquiry. In Proceedings of Asian $\mathrm{CHI}$ Symposium 2019: Emerging $\mathrm{HCl}$ Research Collection (AsianHCl' 19). Association for Computing Machinery, New York, NY, USA, 170-177. doi:https://doi.org/10.1145/3309700.3338462

Khechine, H., Lakhal, S., \& Ndjambou, P. (2016). A meta-analysis of the UTAUT model: Eleven years later. Canadian Journal of Administrative Sciences/Revue Canadienne des Sciences de l'Administration, 33(2), 138-152.

Kline, R. B. (2011). Convergence of structural equation modelling and multilevel modelling. na.

Lutge, E. E., Wiysonge, C. S., Knight, S. E., Sinclair, D., \& Volmink, J. (2015). Incentives and enablers to improve adherence in tuberculosis. Cochrane Database of Systematic Reviews, (9).

McClure, J. B., Hartzler, A. L., \& Catz, S. L. (2016). Design considerations for smoking cessation apps: feedback from nicotine dependence treatment providers and smokers. JMIR mHealth and uHealth, 4(1), e17.

McQuaid, C. F., McCreesh, N., Read, J. M., Sumner, T., Houben, R. M., White, R. G., Harris, R. C., and CMMID COVID-19 Working Group. (2020). The potential impact of COVID-19related disruption on tuberculosis burden. European Respiratory Journal, 56(2).

Quoquab, F., Mohammad, J., Yasin, N. M., \& Abdullah, N. L. (2018). Antecedents of switching Intention in the mobile telecommunications industry: A partial least square approach. Asia Pacific Journal of Marketing and Logistics, 30(4), 1087-1111.

Scott, A. R., Alore, E. A., Naik, A. D., Berger, D. H., \& Suliburk, J. W. (2017). Mixed-methods analysis of factors impacting use of a postoperative mHealth app. JMIR mHealth and uHealth, 5(2), e11.

Seethamraju, R., Diatha, K. S., \& Garg, S. (2018). Intention to use a mobile-based information technology solution for tuberculosis treatment monitoring-applying a UTAUT model. Information Systems Frontiers, 20(1), 163-181.

Skoumpopoulou, D., Wong, A., Ng, P., \& Lo, M. (2018). Factors that affect the acceptance of new technologies in the workplace: a cross case analysis between two universities. International Journal of Education and Development using ICT, 14(3).

Story, A., Garfein, R. S., Hayward, A., Rusovich, V., Dadu, A., Soltan, V., \& Sharma, M. (2016). Monitoring therapy adherence of tuberculosis patients by using video-enabled electronic devices. Emerging infectious diseases, 22(3), 538.

Subbaraman, R., de Mondesert, L., Musiimenta, A., Pai, M., Mayer, K. H., Thomas, B. E., \& Haberer, J. (2018). Digital adherence technologies for the management of tuberculosis therapy: mapping the landscape and research priorities. BMJ Global Health, 3(5), e001018.

Suki, N. M., \& Suki, N. M. (2017). Modeling the determinants of consumers' attitudes toward online group buying: Do risks and trusts matters? Journal of Retailing and Consumer Services, 36, 180-188.

The World Bank. (2017). Mobile cellular subscriptions (per 100 people) - International Telecommunication Union. International Telecommunication Union, World Telecommunication/ICT Development Report and Database. Retrieved from: http://data.worldbank.org/indicator/IT. CEL.SETS.P2. 
Tok, P. S. K., Liew, S. M., Wong, L. P., Razali, A., Loganathan, T., Chinna, K., Ismail, N., and Kadir, N. A. (2020). Determinants of unsuccessful treatment outcomes and mortality among tuberculosis patients in Malaysia: A registry-based cohort study. PloS one, 15(4), e0231986.

Uplekar, M., Weil, D., Lonnroth, K., Jaramillo, E., Lienhardt, C., Dias, H. M., Falzon, D., Floyd, K., Gargioni, G., Getahun, H., and Gilpin, C. (2015). WHO's new end TB strategy. The Lancet, 385(9979), 1799-1801.

Venkatesh, V., Morris, M. G., Davis, G. B., \& Davis, F. D. (2003). User acceptance of information technology: Toward a unified view. MIS quarterly, 425-478.

Venkatesh, V., \& Zhang, X. (2010). Unified theory of acceptance and use of technology: US vs. China. Journal of global information technology management, 13(1), 5-27.

Wang, E. S. T., \& Chou, N. P. Y. (2016). Examining social influence factors affecting consumer continuous usage intention for mobile social networking applications.

World Health Organization. (2015). Digital health for the End TB Strategy: an agenda for action (No. WHO/HTM/TB/2015.21). World Health Organization.

World Health Organization. Global Tuberculosis Report 2019. Geneva, WHO, 2019.

Wingfield, T., Cuevas, L. E., MacPherson, P., Millington, K. A., \& Squire, S. B. (2020). Tackling two pandemics: a plea on World Tuberculosis Day. The Lancet Respiratory Medicine, 8(6), 536-538.

Wu, Y., Yao, X., Vespasiani, G., Nicolucci, A., Dong, Y., Kwong, J., Li, L., Sun, X., Tian, H., and Li, S. (2017). Mobile app-based interventions to support diabetes self-management: a systematic review of randomized controlled trials to identify functions associated with glycemic efficacy. JMIR mHealth and uHealth, 5(3), e35.

Yadav, R., Sharma, S. K., \& Tarhini, A. (2016). A multi-analytical approach to understand and predict the mobile commerce adoption. Journal of enterprise information management, 29(2), 222-237.

Yuan, S., Ma, W., Kanthawala, S., \& Peng, W. (2015). Keep using my health apps: Discover users' perception of health and fitness apps with the UTAUT2 model. Telemedicine and e-Health, 21(9), 735-741. 